\title{
Quality of life of patients with type 2 diabetes mellitus in Mosul
}

\author{
Wafaa Abdul Aziz Mostafa*, Mohammad Yousif Almkhtar** \\ * M.sc. Candidate, **Department of Community Medicine, College of Medicine, University of Mosul.
}

(Ann. Coll. Med. Mosul 2012; 38 (1): 20-26).

Received: $23^{\text {th }}$ Feb. 2011; Accepted: $4^{\text {th }}$ Dec. 2011.

\begin{abstract}
Background: Prevalence of diabetes mellitus is increasing in developed and developing countries. Diabetes is known to strongly affect the health-related quality of life (HRQOL).

Objectives: To assess the quality of life of patients with type 2 diabetes mellitus and to determine the clinical and sociodemographic factors that affect the quality of life of these patients.

Patients and methods: This was a case series health center based study, the data for this research was taken from an MSc research during the data collectinon phase. A 300 patients with type 2 diabetes mellitus attending AL-Wafaa Diabetic Centre in Mosul. The world health Organizations quality of life assessment (WHOQOL-BREEF), short version questionnaire was applied to assess quality of life after being modified and translated to local Arabic language.

Results: The overall QOL show that most of the respondents performed fairly well on the questionnaire used, $41 \%$ had good score, $46 \%$ had fair score and $13 \%$ had poor score. For physical activity domain $30 \%$ had poor score, for social domain $14 \%$ had poor score, for psychological and enviromental domains $23 \%$ had poor score.

Conclusion: This study supports previous reports that $\mathrm{QOL}$ of patients with diabetes mellitus was fairly good and D.M significantly affects physical health especially in females. Further community based cross sectional studies is recommended for measuring QOL in DM.
\end{abstract}

Keywords: Type 2 diabetes mellitus, quality of life.

الخلاصة

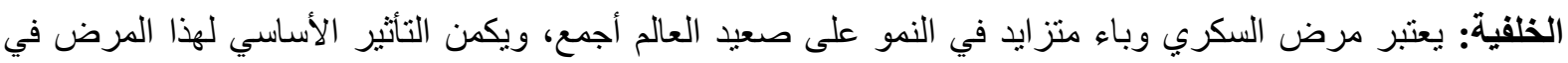

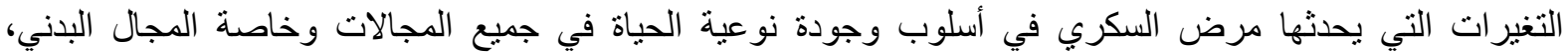
الاجتماعي و العاطفي. الهـف: تهدف هذه الدر اسة إلى تقييم نوعية الحياة لمرضى السكري من النمط ب وتحديد العوامل السريرية والاجتماعية

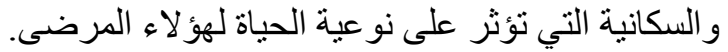

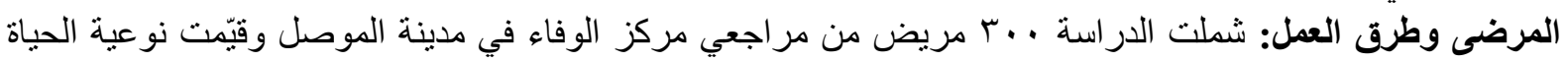
باستخدام استمارة استبيان لمنظمة الصحة العنة العالمية.

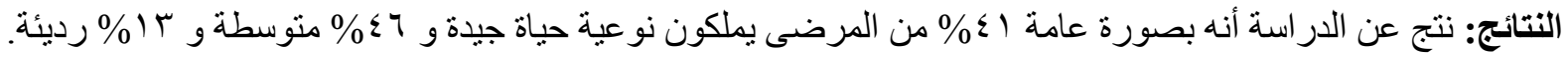

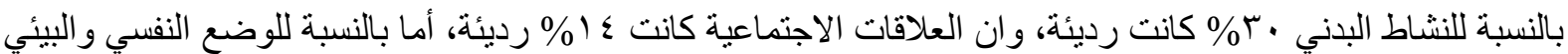

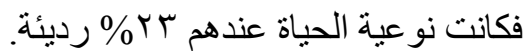

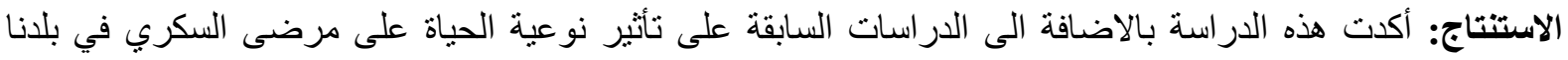
و الناحية البدنية وخاصة بالنسبة للمرضى الإناث، ومن الضروري العمل على زيادة الدراسات التي تهدف التى دراسة التئة نو عية حياة مرضى السكري. 
D iabetes mellitus is one of the chronic non-communicable diseases that is plaguing both developed and developing countries at an alarming rate ${ }^{(1)}$. It has reached epidemic proportion.

According to World Health Organization (WHO): there is an apparent epidemic of diabetes which is strongly related to economic and life style changes. It is now vastly visible as a growing health problem in developing economies as almost $80 \%$ of diabetes deaths occur in low and middle income countries ${ }^{(2)}$. In Iraq, according to the national chronic noncommunicable diseases risk factor survey done in 2006 , the prevalence of DM is $10.4 \%$ (3)

Diabetes mellitus is a demanding disease that affects a person's health- related quality of life, a person's ability to function, they have to eat carefully, exercise, test their blood glucose and based on the result decide when to schedule their next meal or medication ${ }^{(4-7)}$.

Quality of life (QOL): is of central concern in evaluative research and improved quality of life is probably the most desired outcome of all healthcare policies ${ }^{(8)}$. QOL has been defined as a "descriptive term that refers to people's emotional, social and physical well being and their ability to function in the ordinary tasks of living" ${ }^{(9,10)}$. Health related quality of life (HRQOL), on the other hand, includes domains (aspects) of life that improve when a treatment option is successful. A clinically significant change in (HRQOL) is indicated by a decline in a domain that leads a physician or health care provider to alter a medication or medical treatment. (HRQOL) domains minimally include physical state, mental health or emotional wellbeing. These domains represent typical outcomes in medical and social science research ${ }^{(11,12)}$. Numerous studies have been done to evaluate the effect of DM on the sufferer's QOL in the developed

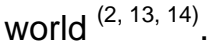

We aim to assess the QOL of our patients with T2DM and to determine the clinical and socio-demographical factors that affect the $\mathrm{QOL}$ of these patients.

\section{Patients and methods}

Approval of study proposal has been obtained through a seminar at the Community Medicine Department. Therefore essential official permissions have been obtained from Nineveh Health Office to conduct this study.

\section{Settings}

The study was done in AL-Wafaa Diabetic Center during the period spanning from September 2010 to March 2011. The data in this study was a part of MSc research done in this centre. This centre is attached to Ibn Sena Teaching Hospital at the West side of Mosul City - North of IRAQ which has been established in 1999.

This is a case-series study, the patients were aged twenty years and above of both sexes; all patients had T2DM diagnosed by the consultant endocrinologist; DM of the young (less than 20 years), gestational DM and duration since diagnosis less than 1 year are excluded from this study. The patients were interviewed by the researcher after being informed and consent of patients were obtained.

\section{Questionnaire}

The instrument used is the World Health Organization quality of life questionnaire-short version (WHOQOL-BREEF) which is a generic instrument with cross -cultural application and has been used as a measure of HRQOL for chronic medical illnesses in many researches in the Middle East and Asian countries $(1,10,13,15,16)$. This questionnaire is modified, translated and approved by the staff of Community Medicine department of College of Medicine, University of Mosul to fit with local traditon and language (Appendix). The WHOQOL-BREEF contains four specific domains which include: physical health, psychological well being, social relationships and environmental condition.

Some limited socio-demographics characterstics (e.g. age, sex, marital status, educational level) and disease related information (e.g. duration of diabetes, family history of diabetes) were also considered.

Scores were used for each question, then the median score calculated in the four domains, 
the scores of items within each domain are used to calculate domain scores.

A score of mean \pm 1 standard deviation (SD) on each domain is graded 'fair', a score of < mean - 1 SD is 'poor', and a score of $>$ mean + $1 \mathrm{SD}$ is $\operatorname{good}^{(15)}$.

\section{Statistical analysis}

Data collected were entered into Microsoft excel and loaded into the Statistical Package for Social Sciences (SPSS) software (version 16 Chicago IL USA) for descriptive statistical analyses.

\section{Results}

Three hundreds consecutive attendees of the diabetes clinic met the inclusion criteria during the course of the study; 169 were females and 131 were males. For overall QOL, 123 (41\%) had good score,138 (46\%) had a fair score and 39 (13\%) had poor score, Table (1).
Those patients with mean age of (51.23) years had good score, while those with mean age of (54.34) had fair score and patients with poor score had mean of age (55.97), Table(2).

The QOL in both physical and psychological domain were inversely related to increasing age of the patients. Regarding duration of illness, those patients with mean duration of (8.86) years had poor score while those of good score mainly had a mean of (6.65) years, Table (3).

The QOL score is high in all the domains except in environmental domain at which the majority of patients had fair to poor score and only (38) patients had good score, in the four domains the QOL score is higher in males than in females, for example, in physical health domain more than half (79) patients from (126) patients who had good score were males and the remaining were females, Table (4).

Table (1): Relationship between qualities of life outcomes and sociodemographic variables.

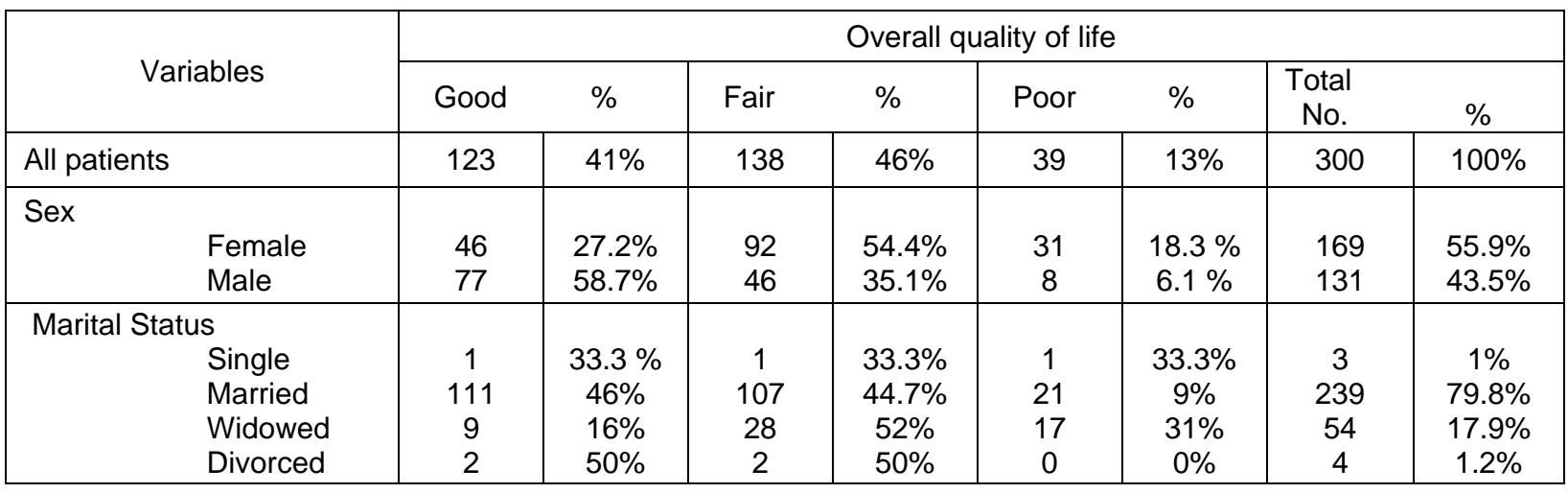

Table (2): Quality of life and patients' characteristics.

\begin{tabular}{|l|c|c|c|}
\hline \multirow{2}{*}{ Variables } & \multicolumn{3}{c|}{ Overall quality of life } \\
\cline { 2 - 4 } & Good & Fair & Poor \\
\hline \multirow{2}{*}{ Mean Age (SD) [Years] } & 51.234 & 54.435 & 55.795 \\
& $(9.199)$ & $(7.797)$ & $(7.164)$ \\
\hline Mean Duration of IIIness (SD) [Years] ${ }^{\star \star}$ & 6.309 & 7.449 & 9.769 \\
& $(5.105)$ & $(5.588)$ & $(7.143)$ \\
\hline Family History of Diabetes Mellitus & 123 & 138 & 39 \\
Yes (1) & 88 & 113 & 33 \\
No (2) & 35 & 25 & 6 \\
\hline
\end{tabular}

${ }^{*} \mathrm{P}<0.05{ }^{* * P} \mathrm{P}<0.05{ }^{* * * P} \mathrm{P}<0.05$. 
Table (3): Quality of life and patients' characteristics according to domains.

\begin{tabular}{|c|c|c|c|c|c|c|c|c|c|c|c|c|}
\hline \multirow{2}{*}{ Variables } & \multicolumn{3}{|c|}{$\begin{array}{c}\text { Domain } 1 \\
\text { Physical health }\end{array}$} & \multicolumn{3}{|c|}{$\begin{array}{c}\text { Domain } 2 \\
\text { Psychological well being }\end{array}$} & \multicolumn{3}{|c|}{$\begin{array}{l}\text { Domain } 3 \\
\text { Social relation ship }\end{array}$} & \multicolumn{3}{|c|}{$\begin{array}{c}\text { Domain } 4 \\
\text { Environmental }\end{array}$} \\
\hline & Good & Fair & Poor & Good & Fair & Poor & Good & Fair & Poor & Good & Fair & Poor \\
\hline $\begin{array}{c}\text { Mean } \\
\text { Age (SD) } \\
\text { [Years] }\end{array}$ & $\begin{array}{l}49.169 \\
(8.822)\end{array}$ & $\begin{array}{l}55.762 \\
(7.494)\end{array}$ & $\begin{array}{l}56.156 \\
(6.876)\end{array}$ & $\begin{array}{l}51.070 \\
(8.421)\end{array}$ & $\begin{array}{l}54.049 \\
(8.840)\end{array}$ & $\begin{array}{l}56.362 \\
(6.894)\end{array}$ & $\begin{array}{l}53.430 \\
(8.606)\end{array}$ & $\begin{array}{l}53.090 \\
(8.418)\end{array}$ & $\begin{array}{l}53.310 \\
(8.406)\end{array}$ & $\begin{array}{l}52.447 \\
(9.258)\end{array}$ & $\begin{array}{l}53.539 \\
(8.299)\end{array}$ & $\begin{array}{l}53.113 \\
(8.658)\end{array}$ \\
\hline $\begin{array}{l}\text { Mean } \\
\text { Duration } \\
\text { of Illness } \\
\text { (SD) } \\
\text { [Years] }\end{array}$ & $\begin{array}{c}6.659 \\
(5.229)\end{array}$ & $\begin{array}{c}6.524 \\
(5.217)\end{array}$ & $\begin{array}{l}8.867 \\
(6.401)\end{array}$ & $\begin{array}{l}6.556 \\
(5.338)\end{array}$ & $\begin{array}{l}7.223 \\
(5.728)\end{array}$ & $\begin{array}{c}8.710 \\
(6.037)\end{array}$ & $\begin{array}{c}7.279 \\
(5.317)\end{array}$ & $\begin{array}{l}6.530 \\
(5.931)\end{array}$ & $\begin{array}{c}9.059 \\
(6.160)\end{array}$ & $\begin{array}{c}6.974 \\
(5.370)\end{array}$ & $\begin{array}{l}7.005 \\
(5.329)\end{array}$ & $\begin{array}{c}8.197 \\
(6.663)\end{array}$ \\
\hline $\begin{array}{l}\text { Family } \\
\text { History } \\
\text { of } \\
\text { Diabetes } \\
\text { Mellitus }\end{array}$ & 126 & 84 & 90 & 129 & 102 & 69 & 158 & 100 & 42 & 38 & 191 & 71 \\
\hline $\begin{array}{l}\text { Yes } \\
\text { No }\end{array}$ & $\begin{array}{l}99 \\
27\end{array}$ & $\begin{array}{l}61 \\
23\end{array}$ & $\begin{array}{l}74 \\
16\end{array}$ & $\begin{array}{c}100 \\
29\end{array}$ & $\begin{array}{l}80 \\
22\end{array}$ & $\begin{array}{l}54 \\
15\end{array}$ & $\begin{array}{c}119 \\
39\end{array}$ & $\begin{array}{l}76 \\
24\end{array}$ & $\begin{array}{c}39 \\
3\end{array}$ & $\begin{array}{c}29 \\
9\end{array}$ & $\begin{array}{c}148 \\
43\end{array}$ & $\begin{array}{l}57 \\
14\end{array}$ \\
\hline
\end{tabular}

Table (4): Relationship between quality of life outcomes and sociodemographic variables according to domains.

\begin{tabular}{|c|c|c|c|c|c|c|c|c|c|c|c|c|}
\hline \multirow[t]{2}{*}{ Variables } & \multicolumn{3}{|c|}{$\begin{array}{c}\text { Domain } 1 \\
\text { Physical health }\end{array}$} & \multicolumn{3}{|c|}{$\begin{array}{c}\text { Domain } 2 \\
\begin{array}{c}\text { Psychological well } \\
\text { being }\end{array}\end{array}$} & \multicolumn{3}{|c|}{$\begin{array}{c}\text { Domain } 3 \\
\text { Social relation ship }\end{array}$} & \multicolumn{3}{|c|}{$\begin{array}{c}\text { Domain } 4 \\
\text { Environmental }\end{array}$} \\
\hline & Good & Fair & Poor & Good & Fair & Poor & Good & Fair & Poor & Good & Fair & Poor \\
\hline $\begin{array}{l}\text { Sex } \\
\text { Female } \\
\text { Male }\end{array}$ & $\begin{array}{c}126 \\
47 \\
79\end{array}$ & $\begin{array}{l}84 \\
50 \\
34\end{array}$ & $\begin{array}{l}90 \\
72 \\
18\end{array}$ & $\begin{array}{l}129 \\
53 \\
76\end{array}$ & $\begin{array}{c}102 \\
62 \\
40\end{array}$ & $\begin{array}{l}69 \\
54 \\
15\end{array}$ & $\begin{array}{c}158 \\
74 \\
84\end{array}$ & $\begin{array}{c}100 \\
60 \\
40\end{array}$ & $\begin{array}{c}42 \\
35 \\
7\end{array}$ & $\begin{array}{c}38 \\
7 \\
31\end{array}$ & $\begin{array}{c}191 \\
110 \\
81\end{array}$ & $\begin{array}{l}71 \\
52 \\
19\end{array}$ \\
\hline $\begin{array}{c}\text { Marital Status } \\
\text { Single } \\
\text { Married } \\
\text { Widowed } \\
\text { Divorced }\end{array}$ & $\begin{array}{c}126 \\
1 \\
116 \\
7 \\
2\end{array}$ & $\begin{array}{c}84 \\
1 \\
63 \\
19 \\
1\end{array}$ & $\begin{array}{c}90 \\
1 \\
60 \\
28 \\
1\end{array}$ & $\begin{array}{c}129 \\
1 \\
114 \\
11 \\
3\end{array}$ & $\begin{array}{c}102 \\
1 \\
81 \\
19 \\
1\end{array}$ & $\begin{array}{c}69 \\
1 \\
44 \\
24 \\
0\end{array}$ & $\begin{array}{c}158 \\
1 \\
137 \\
19 \\
1\end{array}$ & $\begin{array}{c}100 \\
2 \\
73 \\
22 \\
3\end{array}$ & $\begin{array}{c}42 \\
0 \\
29 \\
13 \\
0\end{array}$ & $\begin{array}{c}38 \\
0 \\
35 \\
2 \\
1\end{array}$ & $\begin{array}{c}191 \\
1 \\
154 \\
35 \\
1\end{array}$ & $\begin{array}{c}71 \\
2 \\
50 \\
17 \\
2\end{array}$ \\
\hline
\end{tabular}

\section{Discussion}

The present study found that the overall perception of (HRQOL) of patients with DM was actualy affected by the disease. The result of a previous study showed that patients with DM exprienced a good QOL in comparison to other chronic disease groups and even to healthy population and the majority of patients with T2DM experience a high degree of wellbeing, satisfaction and enjoyment ${ }^{(15)}$.

In this study it was seen that there is a decrease in HRQOL with increasing mean age of the patients; this is similar to the result of a study in Saudi Arabia ${ }^{(13)}$.

There is a clearly visibile effect of gender on QOL; female patients had low score in QOL compared to males. This may be due to the high prevalence of obesity in female patients in our locality, this result is similar to other studies (13,15-17). Regarding to duration of illness, poor QOL is related to high mean of duration of illness; this is likely due to the appearance of complications with time. A study in Saudi Arabia showed that the duration of illness had no significant effect on QOL ${ }^{(13)}$, while Swedish bases population study which reported that the duration of disease significantly correlate with $\mathrm{QOL}$, and notice that subject with duration more than 5 years had better $\mathrm{QOL}^{(18)}$. This may be due to good control and adaptation of the patients with diabetic life style. Another study in Kuwiat ${ }^{(16)}$ showed that the duration of illness had a significant impact only on the environmental domain. 
The social domain which assesses personal relationships showed a high mean score in (HRQOL) of our patients; this probably is due to a very large extent to high degree of satisfaction to the items of this domain. This finding however was similar to a previous study by Awadalla et al ${ }^{(16)}$ who reported no difference in the score of patients with diabetes in relation to general population on the social relationships domain. It is worthy of note that Awadalla et al patients had a good level of social support and had strong family care giver support system. It has been shown that the family is a major source of support reflecting better psychological adjustment of the patient to the disease ${ }^{(16)}$.

In respect to environment domain this research demonstrated that the majority of patients got fair score. This does not agree with other studies ${ }^{(17,19)}$, which revealed that: the score of the environment domain was much lower than the other three domains and this could be due to bad environmental condition in these localities.

The major limitations of this study are the health center based sample in that it may not be representative of patients with diabetes mellitus throughout Mosul, although it is the main center in the city. As there are no previous studies on QOL of patients with diabetes mellitus using the (WHOQOLBREEF) in IRAQ, direct comparison with other studies is difficult.

\section{Conclusion}

This study supports previous reports that QOL of patients with diabetes mellitus was fairly good and D.M significantly affects physical health especially in females.

Further community based cross sectional studies is recommended for measuring $\mathrm{QOL}$ in DM.

\section{References}

1. Valentine U, Odili LU, Oparah A, et al. Quality Of Life of People with Diabetes in Benin City as Measured with WHOQOLBREEF, The Internet Journal of Law, Healthcare and Ethics 2010;6 (2): 1-11.

2. King $\mathrm{H}$. Global burden of diabetes 19952025: Prevalence, numerical estimates and projections. Diabetes care 1998; 21 (9): 1414-31.

3. $\mathrm{MOH}$, Iraq. Central Organization for Statistics and information Technology (COSIT), WHO (2006). Noncommunicable diseases risk factors health survey. Baghdad: WHO Iraq.

4. Sigurdardottir AK, Bendiktsson $R$, Jonsdottir $\mathrm{H}$. Instruments to tailor care of people with type 2 diabetes. Journal of Advanced nursing 2009; 65(10):2119-130.

5. Rubin RR, Diabetes and quality of Life. Diabetes Spectrum 2000; 13:2000-21.

6. Snoek FJ, Welch GR, Pouwer F, Polonsky $\mathrm{WH}$. Diabetes - related emotional distress in Dutch and U.S. diabetic patients. Diabetes Care 2000; 23:1305-09.

7. Farquhar M. Definitions of quality of life: $A$ taxonomy. Journal of Advanced Nursing 1995; 22 (3): 502-508.

8. Donald A. What is Quality of life? Hayward Medical Communication. 2010:1(9) [cited July 2, 2010]. Available from: URL: http:// www.evidence-based-medicine. co. UK.

9. Von Steinbuchel N, Lishetzke T, Gurny M, Eid M. Assessing quality of life in older people: Psychometric properties of the WHOQOL-BREEF. Eur J Ageing 2006; 3: 116-122.

10. Albert, SM, Teresi, JA. Quality of Life, Definition and Measurement. Encyclopaediaof aging. 2002 [cited July 2, 2010]. Available form: URL: http://www. encyclopedia.com/doc/1G2-3402200344. html.

11. Buresova G, Veleminsky M Jr, Veleminsky M Sr. Health related quality of life of children and adolescents with type 1 diabetes. Neuro Endocrinol Lett. 2008; 29(6):1045-53.

12. Redekop WK, Koopmanschap MA, Stolk RP, Rutten GE, Wolffenbuttel BH, Niessen LW. Health-related quality of life and treatment satisfaction in Dutch patients with type 2 diabetes. Diabetes Care 2002; 25:458-463.

13. ALshehri A, Taha A, Abahnassy A, Salah $M$. Health related quality of life in type 2 diabetic patients, Ann Saudi Med 2008; 28(5):352-360. 
14. Saatcioglu Ö, Cerlikel F, Kutluturk F, Cumurcun B, Kisacik B. Disability and quality of life in patients with type 2 Diabetes Mellius. Istanbul Bakirkoy Research Hospital for Psychiatry, Neurology and Neurosurgery $\mathrm{AJCl}, 2008$; 2(3):106-112.

15. Issa BA, Baiyewu O. Quality of Life of Patients with Diabetes Mellitus in a Nigerian Teaching Hospital, Hong Kong J Psychiatry 2006;16:27-33.

16. Awadalla AW, Ohaeri UJ, Tawfiq MA, AlAwadi AS. Subjective Quality of Life of outpatients with diabetes: comparison with Family caregiver's impression and control group. J Natl Med Assoc. May 2006; 98(5): 737-45.
17. Eljedi A, Mikolajczyk RT, Kraemer A, Laaser U. Health-related quality of life in diabetic patients and controls without diabetes in refugee camps in the Gaza strip: a cross-sectional study BMC Public Health 2006; 6:268.

18. Wang Shi L, Wang K. Assessment of quality of life in patients with diabetes mellitus and impaired glucose tolerance. Zhonghnaya Fang Yi Xue Za Zhi 2001; 35(1): 21-29.

19. Aghamollaei T, Eftekhar H, Shojaeizadeh D, Mohammad K, Nakhjavani M, Ghofrani Pour F. Behavior, Metabolic Control and Health-related Quality of Life in Diabetic Patients at Bandar Abbas Diabetic Clinic. Iranian J publ Health 2003;32:54-59. 


\section{Appendix}

\section{Study questionnaire form}

Serial number Name Age:

Sex: male female

Marital state: single married widowed divorced

Family history of diabetes: yes no

Duration of illness:( ) years

Quality of life questionnaire

A-Physical health:

1-Energy and fatigue.

2-Pain and discomfort.

3-Sleep and rest.

4-Activity on daily living.

5-Mobility.

6-Depend on medical.

7-Work capacity.

\section{B- Psychological health}

1-Bodily image and appearance.

2-Negative feeling.

3- Positive feeling.

4-Self esteem.

5-Thinking, learning, memory and concentration.

\section{C-Social relationship}

1-Personal relation.

2-Social support.

\section{D-Environmental state}

1 -Financial resources.

2-Freedom, physical safety and security.

3-Health and social care.

4-Home environment.

5-Opportunities for acquiring new information and skills.

6-Participation and opportunities for recreation and leisure.

7-Physical environment (noise, pollution, climate).

8-Transport. 